\title{
Bermain Dengan Media TASRU (Kertas Kokoru) Untuk Mengembangkan Motorik Halus Anak
}

\author{
Dini Oftaviani ${ }^{1}$, Shofitri Christina Dianita², Cari Riskiana3 ${ }^{3}$, Intan Prastihastari Wijaya4 \\ dini.oftaviani@gmail.com, shofitricd01@gmail.com, caryriskiana98@gmail.com, \\ intanwijaya@unpkediri.ac.id \\ 1,2,3,4 PG-PAUD, Universitas Nusantara PGRI Kediri
}

\begin{abstract}
Fine motor skills are very useful for children to complete activities in life, especially those related to skills. Fine motor development will train children to be skilled in using their hands and fingers and coordinating their eyes in a balanced way. However, children's fine motor skills will not develop just like that, so that if there is no stimulus from an early age, the child's fine motor skills will be very low. To overcome this, the activity of playing with tasru media (paper kokoru) provides the latest solution related to the development of children's fine motor skills. Based on these problems, this study aims to develop fine motor skills in early childhood by playing using Tasru media (Kokoru Paper). This study uses the Kemmis and Taggart model of classroom action research which consists of four stages, namely planning, implementation, observation, and reflection which is carried out in 3 cycles, namely Cycle I, Cycle II, and Cycle III. Based on the data obtained in the first cycle of 50\% which is classified in the category is still low. Furthermore, in the second cycle there was an increase of $14 \%$ so that it became $64 \%$ but did not meet the learning completeness criteria. Then in the third cycle there was another increase of $19 \%$ so that the achievement of the percentage in the third cycle was $83 \%$ and had exceeded the learning mastery of $75 \%$. So it can be concluded that playing with Tasru media (Kertas Kokoru) can develop fine motor skills of children in group B PAUD (KB) AL-FIKR Banaran Kediri City.
\end{abstract}

Keywords: Media, Fine motor, Tasru

Abstrak
Kemampuan motorik halus sangat berguna bagi anak untuk menyelesaikan kegiatan dalam kehidupannya
terutama yang berkaitan dengan keterampilan. Pengembangan motorik halus akan melatih anak agar
terampil menggunakan tangan dan jari jemari serta mengkoordinasi mata dengan seimbang. Namun
kemampuan motorik halus anak tidak akan berkembang begitu saja, sehingga jika tidak ada stimulus sejak
dini, maka kemampuan motorik halus anak akan menjadi sangat rendah. Untuk mengatasi hal tersebut, maka
kegiatan bermain dengan media tasru (kertas kokoru) memberikan solusi terbaru terkait pengembangan
motorik halus anak. Berdasarkan pada permasalahan tersebut, maka penelitian ini bertujuan untuk
mengembangkan motorik halus anak usia dini dengan bermain menggunakan media Tasru (Kertas Kokoru).
Penelitian ini menggunakan penelitian tindakan kelas model Kemmis dan Taggart yang terdiri dari empat
tahap yaitu perencanaan, pelaksanaan, pengamatan, dan refleksi yang dilakukan sebanyak 3 siklus yaitu
Siklus I, Siklus II, dan Siklus III. Berdasarkan data yang diperoleh pada siklus I sebesar $50 \%$ yang tergolong
dalam kategori masih rendah. Selanjutnya, pada siklus II mengalami peningkatan $14 \%$ sehingga menjadi $64 \%$
tetapi belum memenuhi kriteria ketuntasan belajar. Kemudian pada siklus III terdapat peningkatan lagi
sebesar $19 \%$ sehingga pencapaian persentase pada siklus III yaitu $83 \%$ dan sudah melampaui ketuntasan
belajar yaitu $75 \%$. Maka dapat disimpulkan bahwa bermain dengan media Tasru (Kertas Kokoru) dapat
mengembangkan kemampuan motorik halus anak kelompok B PAUD (KB) AL-FIKR Banaran Kota Kediri.

Kata kunci : Media, Motorik halus, Tasru 


\section{PENDAHULUAN}

Anak-anak adalah manusia kecil dengan banyak potensi yang perlu diwujudkan. Anak-anak selalu energik, dinamis, antusias, dan ingin tahu tentang apa yang mereka lihat, dengar, dan rasakan, yang membedakan mereka dari orang dewasa. Anak-anak selalu aktif, dinamis, antusias, dan ingin tahu tentang apa yang mereka lihat, dengar, dan rasakan. Anak-anak selalu mengeksplorasi dan menemukan hal-hal baru. Anak-anak menyelidiki dan belajar dari lingkungan mereka saat mereka tumbuh dewasa. Mulai dari keluarga dekat anak, orang tua atau kerabat dekat lainnya, dan guru di berbagai lembaga pendidikan yang memberikan pelayanan kepada PAUD dan masyarakat sekitar. Hal ini dapat membantu anak berkembang dan berkembang secara jasmani dan rohani dengan memberikan rangsangan pendidikan, yang dapat berbentuk pendidikan resmi, nonformal, dan informal.

Pendidikan anak usia dini didefinisikan sebagai suatu upaya pembinaan yang ditunjukkan kepada anak sejak lahir sampai dengan usia enam tahun, yang dilakukan melalui pemberian rangsangan pendidikan untuk membantu pertumbuhan dan perkembangan jasmani, menurut UndangUndang Republik Indonesia Nomor 20 Tahun 2003 tentang Tata Negara. Sistem Pendidikan Bab 1, Pasal 1, Angka 14. kerohanian, agar para pemuda dipersiapkan untuk melanjutkan studinya. Ki Hajar Dewantara menyaring seluruh potensi anak menjadi kreativitas, cita rasa, dan karsa. Menurut hipotesis Gardner tentang kecerdasan ganda, ada delapan jenis kecerdasan.

Ada hubungan antara sel-sel saraf pada periode ini, dan kuantitas serta kualitas hubungan ini mempengaruhi kecerdasan balita. Belahan otak kanan dan kiri berkembang secara bersamaan pada tahap ini. Otak kiri mengatur tugas-tugas yang teratur, berurutan, terperinci, dan sistematis, dan terkait dengan tangan kanan, kaki, dan tubuh. Tangan, kaki, dan tubuh kiri terhubung dengan otak kanan. Berpikir divergen (meluas), imajinasi, ide, kreativitas, emosi, musik, intuisi, abstrak, bebas, dan simultanitas semuanya dikendalikan oleh otak kanan. Untuk mengoptimalkan kecerdasan anak, semua tangan, kaki, mata, telinga kanan dan kiri harus dilatih secara seimbang setiap hari agar otak kiri dan kanan dapat berkembang secara optimal.

Tujuan PAUD dalam hal ini adalah untuk mengarahkan dan mengembangkan potensi setiap anak agar seluruh bagian perkembangannya dapat mencapai potensinya secara maksimal. Menurut Peraturan Menteri Pendidikan dan Kebudayaan Republik Indonesia Nomor 146 Tahun 2014, pasal 5 ayat 1, ada enam bidang perkembangan anak usia dini: nilai agama dan moral, fisik-motorik, kognitif, bahasa, sosial. -emosional, dan artistik3. Jika salah satu atau lebih dari kualitas tersebut dapat dikembangkan dengan benar, anak akan dapat mengembangkan sepenuhnya kemampuan dan potensi yang ada di dalam dirinya. Namun, akan jauh lebih baik jika semua komponen dapat berkembang secara seimbang dan menyeluruh. Perkembangan motorik merupakan salah satu komponen perkembangan yang menjadi subyek inkuiri.

Menurut Hurlock, perkembangan kemampuan motorik anak memerlukan koordinasi gerakan fisik oleh pusat saraf, saraf, dan otot. Alasan mendasar mengapa PAUD diklasifikasikan sebagai aspek atau domain motorik adalah karena perkembangan motorik anak memiliki kaitan yang kuat dengan elemen lain dari perkembangannya, dan perkembangan anak terutama diukur dari bagaimana kemampuan motoriknya tumbuh. Hal ini sesuai dengan pendapat Samsudin yang menyatakan bahwa perkembangan motorik adalah perubahan karakteristik fisik dan psikis yang terjadi selama masa pertumbuhan dan sangat dipengaruhi oleh nutrisi, status kesehatan, dan perawatan motorik. Seorang anak dengan keterampilan motorik yang memadai dapat melakukan suatu kegiatan atau kegiatan yang mendorong pertumbuhan dan perkembangan secara sederhana dan lancar. Keterampilan motorik halus merupakan salah satu bakat motorik yang memerlukan kemampuan yang lebih rumit.

Keterampilan motorik fisik, kemampuan kognitif, kemampuan bahasa, kemampuan sosial emosional, cita-cita agama dan moral, dan kemampuan kreatif adalah semua komponen perkembangan kemampuan. Lembaga pendidikan keluarga dapat digunakan untuk membantu anak usia 5-6 tahun mengembangkan kemampuannya. Pada dasarnya anak masih menginginkan perhatian yang utuh, dan 
perhatian ini secara khusus berdampak pada tahap perkembangan. Fokus penelitian di sini adalah pada kemampuan motorik halus. Kapasitas komponen fisik kemampuan motorik halus dan kasar sebagai pengontrol fisik terstruktur pada kinerja pusat saraf, saraf, dan otot yang berkoordinasi dengan bagian tubuh seperti tangan dan mata, menurut Hurlock (2005). Oleh karena itu, konsep bermain dalam kreativitas sebagai bekal bakat anak menjadi salah satu fokus terpenting pada perkembangan fisik motorik halus selama proses penerapannya. Selanjutnya, proses mengajarkan keterampilan yang diperlukan.

Anak-anak berada di masa keemasan mereka antara usia 5 dan 6. Dimana anak muda dapat menggunakan imajinasinya untuk menciptakan dan mengasah kreativitas siswa saat ini. Kemampuan melipat, menggambar, memotong, menempel, dan mencocokkan merupakan ciri-ciri perkembangan fisik motorik halus pada anak usia 5 sampai 6 tahun. Orang tua dan lingkungan pendidikan dapat mengajari anak tentang kemampuannya. Masa kanak-kanak sering disebut sebagai "waktu bermain". Oleh karena itu, mengetahui cara bermain menjadi bagian penting dalam kegiatan belajar anak. Ini adalah faktor terpenting dalam mengembangkan komponen fisik kemampuan motorik halus tanpa memberikan tekanan yang tidak semestinya pada jiwa atau perasaan anak. Akibatnya, anak-anak lebih cenderung menikmati kegiatan belajar yang sesuai dengan usia mereka.

Kompetensi PAUD pada standar perkembangan fisik motorik anak usia 5-6 tahun. Anak-anak dapat memanfaatkan anggota tubuhnya untuk memperoleh keterampilan motorik kasar dan halus. Anak sudah dapat melakukan gerakan dan aktivitas yang berhubungan dengan perkembangan fisik motorik halus pada usia 5-6 tahun. Menurut tahapannya, anak sudah mampu mengoordinasikan pikiran, mata, dan tangannya dengan baik. Oleh karena itu, untuk memperkuat kemampuan fisik motorik halus anak diperlukan suatu stimulus yang dapat mengembangkan bakat yang dimiliki oleh anak usia dini.

Ketika motorik aktif, ketiga elemen memainkan peran mereka dalam interaksi yang menguntungkan. Artinya, elemen-elemen yang saling berhubungan saling mendukung dan melengkapi satu sama lain untuk menghasilkan kondisi motor yang lebih ideal. Alhasil, ketiga unsur tersebut (otak, saraf, dan otot) berkolaborasi untuk menciptakan suatu aktivitas yang memiliki tujuan, seperti berbicara, berjalan, berlari, menulis, menggambar, dan sebagainya. Keterampilan motorik halus setiap anak adalah unik. Tergantung pada kedewasaan anak, ada yang lambat dan ada yang sesuai dengan perkembangan. Ketika kemampuan motorik halus anak terlambat, itu berarti dia seharusnya bisa mendapatkan keterampilan baru pada usianya tetapi tidak. Karena keterlambatan perkembangan, beberapa anak menunjukkan defisit dalam kemampuan motorik halus. Metode seni merupakan strategi pembelajaran yang membantu meningkatkan kemampuan motorik halus anak guna mengoptimalkan tumbuh kembangnya.

Keterampilan motorik halus, menurut Suyadi, adalah peningkatan sinkronisasi gerakan tubuh yang melibatkan otot dan saraf yang jauh lebih kecil (2010: 68-69). Perkembangan motorik halus memberikan dasar untuk belajar dan memperkuat berbagai keterampilan selama masa kanak-kanak, menurut Owens (2008). Anak-anak dengan masalah keterampilan motorik halus akan frustrasi karena mereka tidak akan dapat melakukan tugas sehari-hari seperti membuat sketsa atau memotong dengan gunting.

Anak-anak dengan masalah keterampilan motorik halus akan frustrasi karena mereka tidak akan dapat melakukan tugas sehari-hari seperti membuat sketsa atau memotong dengan gunting. Pendidikan anak usia dini (PAUD) adalah suatu upaya pembinaan yang ditujukan kepada anak sejak lahir sampai dengan usia enam tahun. Ini adalah tingkat sebelum pendidikan dasar. Anak usia dini menurut Slamet Suyanto (2005:5), ditandai dengan pertumbuhan dan perkembangan yang paling pesat, baik secara fisik maupun kognitif. Pertumbuhan dan perkembangan anak dimulai sebelum lahir, yaitu saat masih dalam kandungan. Produksi sel-sel saraf otak yang menjadi dasar perkembangan kecerdasan berlangsung sejak anak masih dalam kandungan. Perkembangan individu, serta keberadaan bangsa dan negara, semuanya dipengaruhi oleh anak usia dini. Berbagai bidang perkembangan anak mengalami pertumbuhan dan perkembangan yang pesat pada usia tersebut. 
Akibatnya, pertumbuhan yang tepat di usia muda merupakan penentu perkembangan individu di masa depan.

Dalam peraturan Kementerian Pendidikan dan Kebudayaan Republik Indonesia (2014) sifatsifat kemampuan motorik halus anak usia 5 sampai 6 tahun adalah anak-anak dapat menarik yang ditunjukkan dengan pikirannya, meniru bentuk, menyelidiki dengan media dan latihan yang berbeda, menggunakan alat tulis dan peralatan makan secara efektif, mengiris sesuai contoh, menempelkan gambar secara akurat, menempatkan diri di sana melalui pengembangan menggambar seluk beluk, dan bergerak untuk menghasilkan bentuk yang luar biasa dan imajinatif. Gerak inventif di sini adalah metode yang digunakan para ilmuwan untuk mengukur prestasi dalam membina kemampuan mesin halus anak muda melalui latihan bermain dengan media tasru (kertas kokoru).

Gerakan bermain bergerak dengan media tasru (kertas kokoru) adalah membuat lingkaran, atau membuat gulungan-gulungan kecil. Untuk menghadirkan bentuk-bentuk tersebut, anak-anak bisa memanfaatkan jenis kertas kokoru panjang. Dari perkamen-perkamen ini, anak-anak dapat membentuk/mengumpulkan menjadi makhluk, tumbuhan dan karakter animasi yang mereka sukai atau sukai seperti yang ditunjukkan oleh pikiran mereka sendiri. Mengingat konsekuensi dari persepsi tentang latihan bermain yang dikaitkan dengan kemampuan mesin halus, usia 5-6 tahun belum tumbuh secara ideal. Latihan yang dikaitkan dengan keterampilan mesin halus anak-anak berusia 5-6 tahun, seperti latihan bergerak, sangat terbukti bahwa hasilnya tidak terlalu sempurna. Selanjutnya media latihan bermain yang digunakan untuk membina kemampuan motorik halus anak pada kelompok umur jangka panjang kurang memadai, media latihannya hanya membosankan sehingga anak tidak bersemangat melakukan latihan bermain tersebut, sehingga hasilnya tidak sempurna dan tidak tidak berkoordinasi dengan asumsi ideal.

Menumbuhkan kemampuan motorik anak terutama dalam motorik halusnya memang sangatlah penting. karena hal itu mampu membantu anak melatih dan menggerakkan otot-otot kecil untuk melakukan sesuatu seperti mengembangkan tangan dan memperlancar perkembangan. latihan yang dapat membantu anak dalam mengembangkan kemampuan motorik halus adalah melalui latihan bermain dengan memanfaatkan media tasru, karena latihan bermain dengan media tasru dapat mempersiapkan anak menjadi berbakat menggunakan tangan dan jari serta mengatur mata secara wajar dan dapat diandalkan untuk melatih kemampuan motorik halus anak.

Nilai dari media Tasru (Kertas Kokoru) adalah dapat digunakan untuk berbagai bakat kreatif, antara lain menghiasi scarpbook, majalah dinding sekolah, membuat kartu, bingkai foto, dan dekorasi. Buat binatang, mainan, mobil, bangunan, dan benda lain dari kokoru sesuai imajinasimu9. Dengan bentuk bergelombang yang membuat anak membutuhkan tenaga lebih untuk memotongnya, media Kokoru memiliki keunggulan untuk melatih ketangkasan jari anak dalam memotong. Alhasil, jari-jari anak semakin kuat dalam memegang gunting dan menggunting. Selain ketangkasan tangan, media kokoru dapat membantu anak muda mengembangkan kreativitasnya. Dengan pilihan warna yang tersedia, anak-anak bisa imajinatif seperti yang mereka inginkan.

Sedangkan tujuan penggunaan media kokoru adalah untuk mendorong kreativitas anak sekaligus mengembangkan kemampuan motoriknya khususnya motorik halus. Selain memberikan pengalaman yang menyenangkan, menjadi kreatif dapat membantu anak-anak mendapatkan kepercayaan diri dan meningkatkan kreativitas mereka. Jika seorang anak memiliki keterampilan motorik yang tinggi, ia juga akan dapat beradaptasi dengan baik, sehingga memudahkan mereka untuk menjalin pertemanan dengan teman sebayanya (Suryani, 2014: 7)

Media tasru (kertas kokoru) memiliki permukaan lain yang berbeda dengan seluruh kertas. Kertas kokoru diciutkan seperti karton dan memiliki banyak contoh menarik, yang bisa kusam, sedang atau ringan. berbeda dengan kertas origami yang biasa di jumpai dalam kelas maupun pusat perbelanjaan alat tulis, kertas Kokoru umumnya memiliki bahan yang tebal, permukaan yang bergelombang, kertas Kokoru ini juga tersedia 2 macam pilihan. Kokoru diberi bingkai seperti antrian panjang yang biasa disebut dengan Ichi. Sedangkan Kokoru yang berukuran A4 disebut Hachi. Ichi dan 
Hachi memiliki dasar warna yang beragam seperti biru, hijau, putih, merah, oranye, emas dan kuning. Nada-nada ini sangat menarik bagi anak-anak, terutama pada anak usia dini. Kertas kokoru ini memiliki permukaan yang tidak rata, hiasan garis-garis, mudah dibentuk, terutama sangat mudah digerakkan sesuai keinginan dan pikiran kreatif anak-anak.

Media tasru ini dapat dibuat dengan cara digulung atau diciutkan untuk membuat berbagai macam bentuk inovatif seperti yang diharapkan. Alat dan bahan pendamping media tasru (kertas kokoru) akan digerakkan oleh anak-anak untuk membuat berbagai bentuk yang ditunjukkan dengan kreativitas pikiran dan imajinasi anak usia 5-6 tahun. Hasil wawancara serta pengamatan yang telah dilakukan di PAUD (KB) AL-FIKR Banaran Kota Kediri, menunjukkan bahwa kemampuan motorik halus pada anak kelompok $B$ masih rendah. Banyak anak yang belum fokus dengan pembelajaran yang disampaikan. Anak juga kurang aktif serta kurang antusias ketika mengikuti pembelajaran motorik halus yang diberikan oleh guru. Hal ini disebabkan media yang digunakan oleh guru kurang bervariatif. Selain itu, guru sering menggunakan cara pembelajaran yang berulang yaitu dengan mengunakan Lembar Kerja Anak (LKA).

Dengan demikian, guru menjadi kurang kreatif dan sangat monoton dalam melaksanakan pembelajaran motorik halus sehingga anak kurang tertarik dan mudah merasa bosan dengan kegiatan yang diberikan. Dari penjelasan di atas, penulis memilih pembelajaran bermain dengan media Tasru (Kertas Kokoru) guna untuk mengembangkan motorik halus anak. Salah satu alternatif bermain dengan media Tasru (Kertas Kokoru), Suryani (2014) menjelaskan bahwa kokoru merupakan kertas bergelombang yang memiliki aneka warna sehingga anak tidak akan merasa bosan dalam pembelajaran. Kertas kokoru merupakan bahan yang ramah lingkungan dan juga sangat aman untuk dijadikan media dalam bermain untuk anak. Dalam bermain dengan media Tasru (Kertas Kokoru) ini anak dapat belajar bagaimana cara menggulung, menggunting ataupun menempel kertas. Berdasarkan uraian di atas, maka dapat dirumuskan judul sebagai berikut, "Bermain Dengan Media Tasru (Kertas Kokoru) Untuk Mengembangkan Motorik Halus Anak".

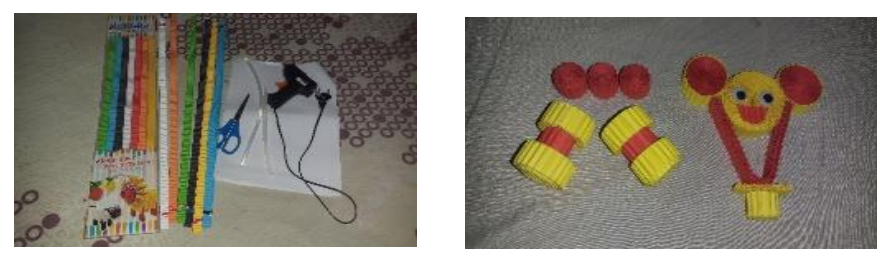

Gambar 1: Media Tasru

\section{METODE PENELITIAN}

Penelitian ini merupakan penelitian yang menggunakan penelitian tindakan kelas yang dikembangkan oleh Arikunto, sebagaimana yang diungkapkan oleh Arikunto dadang iskandar (2015), dengan fokus pada permasalahan yang dikaji menggunakan model Kemmis dan Taggart yang mempunyai empat teknik tahapan yaitu, penyusunan, pelaksanaan, presepsi dan refleksi yang khusus diselesaikan di dalam 3 siklus yaitu siklus 1, siklus 2, siklus 3. Penelitian ini dilaksanakan pada anak kelompok B PAUD (KB) AL-FIKR Banaran Kota Kediri. Subjek yang digunakan adalah anak-anak peserta didik PAUD (KB) AL-FIKR usia 5-6 tahun.

Penelitian ini mengumpulkan informasi mengenai kemampuan perkembangan motorik halus anak kelompok B di PAUD (KB) AL-FIKR Banaran Kota Kediri dengan sebanyak 10 anak. Prosedur pengumpulan informasi dalam penelitian ini menggunakan strategi evaluasi pelaksanaan melalui siswa untuk menyelesaikan latihan yang dilihat oleh instruktur. Sedangkan ragam informasi tentang pelaksanaan pembelajaran diperoleh melalui metode observasi dengan memanfaatkan lembar observasi. Selain itu, penelitian ini menggunakan metode investigasi informasi untuk menguji spekulasi aktivitas, yaitu prosedur kuantitatif spesifik dengan membandingkan pemenuhan pembelajaran (nilai 
yang mendapat nilai 3 adalah Menciptakan Sesuai Asumsi dan nilai 4 secara keseluruhan Tumbuh Baik) antara waktu sebelumnya, kemudian setelah adanya kegiatan Siklus 1, kegiatan Siklus 2 dan kegiatan Siklus 3.

\section{HASIL DAN PEMBAHASAN}

Penelitian yang dilakukan oleh peneliti ini menggunakan 3 siklus. Setiap siklusnya terdiri dari 4 tahap yaitu yang pertama tahap perencanaan yang meliputi penyusunan Rencana Pelaksanaan Pembelajaran Mingguan (RPPM), Rencana Pelaksanaan Pembelajaran Harian (RPPH), menyiapkan media tasru dan menyiapkan instrumen penilaian. Kedua, tahap pelaksanaan yang berisi tentang penjelasan tema, penjelasan media tasru cara membuat media tasru, Ketiga, tahap pengamatan meliputi pengamatan kemampuan motorik halus anak dalam menggulung, Keempat, tahap refleksi yaitu meninjau kembali dari pengamatan yang diperoleh dan permasalahan yang timbul pada saat kegiatan pembelajaran berlangsung, akan menjadi dasar untuk melakukan perencanaan ulang pada siklus berikutnya. Melakukan beberapa perbaikan supaya permasalahan dapat teratasi. Siklus I pada penelitian ini dilakukan pada tanggal 10 Februari 2021, siklus 2 pada 17 Februari 2021 dan siklus 3 pada 24 Februari 2021, sehingga dihasilkan data sebagai berikut :

\section{Tabel 1. Hasil Penilaian Unjuk Kerja KemampuanMenggulung Menggunakan Media Tasru (Kertas Kokoru)}

\begin{tabular}{|c|c|c|c|}
\hline Siklus & Perilaku Yang Diamati & Frekuensi & $\begin{array}{l}\text { Persentase } \\
\text { Keberhasilan }\end{array}$ \\
\hline Siklus 1 & $\begin{array}{l}\text { Kemampuan bermain } \\
\text { menggulung media tasru }\end{array}$ & $\begin{array}{l}\text { BM : } 9 \\
\text { MM : } 3 \\
\text { BSH: } 3 \\
\text { BSB: } 3\end{array}$ & $50 \%$ \\
\hline Siklus 2 & $\begin{array}{l}\text { Kemampuan bermain } \\
\text { menggulung media tasru }\end{array}$ & $\begin{array}{l}\text { BM : } 4 \\
\text { MM }: 5 \\
\text { BSH :4 } \\
\text { BSB :5 }\end{array}$ & $64 \%$ \\
\hline Siklus 3 & $\begin{array}{l}\text { Kemampuan bermain } \\
\text { menggulung media tasru }\end{array}$ & $\begin{array}{l}\text { BM }: 1 \\
\text { MM }: 3 \\
\text { BSH }: 4 \\
\text { BSB }: 10\end{array}$ & $83 \%$ \\
\hline
\end{tabular}

Keterangan:

$\begin{array}{ll}\text { BM } & \text { : Belum Muncul } \\ \text { MM } & \text { : Mulai Muncul } \\ \text { BSH } & \text { : Menciptakan bentuk yang benar } \\ \text { BSB } & \text { : Tumbuh cukup baik }\end{array}$

Dapat dilihat dari tabel 1 bahwa persentase keberhasilan anak didik di Siklus I, Siklus II dan yang terakhir Siklus III perlahan-lahan mengalami peningkatan. Selain itu, dari tabel 1 di atas juga menunjukkan hasil penilaian unjuk kerja anak pada kemampuan bermain menggulung media tasru angka pada siklus I sebesar 50\% yang tergolong dalam kategori masih rendah. Selanjutnya, pada siklus II mengalami peningkatan $14 \%$ sehingga menjadi $64 \%$ tetapi belum memenuhi kriteria ketuntasan belajar. Kemudian pada siklus III terdapat peningkatan lagi sebesar 19\% sehingga pencapaian persentase pada siklus III yaitu $83 \%$ dan sudah melampaui ketuntasan belajar yaitu $75 \%$.

Pada siklus III diperoleh persentase yang melampaui ketuntasan belajar sehingga hipotesis yang berbunyi "Bermain dengan media tasru dapat mengembangkan kemampuan motorik halus dalam 
menggulung pada anak usia 5- 6 tahun.Berikut bukti dokumentasi kegiatan bermain dengan media tasru (kertas kokoru) yang dilakukan anak didik kelompok B usia 5-6 tahun :
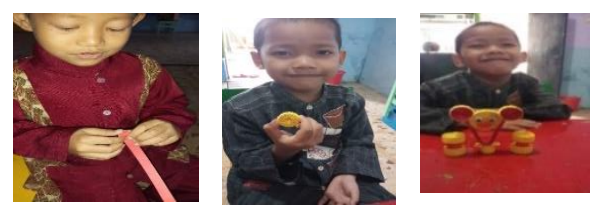

Gambar 2 Kegiatan anak pada sikuls 1, 2, dan 3

Jika ditampilkan menggunakan diagram batang, maka akan seperti gambar di bawah ini :



\section{Gambar 3. Persentase Keberhasilan Motorik Halus Anak}

Pada siklus ketiga terlihat jelas pada gambar diagram batang bahwa siklus ketiga menunjukkan persentase yang sangat baik yaitu $83 \%$, ini berarti sudah melampaui batas ketuntasan belajar, sehingga hipotesis yang berbunyi " Tindakan pembelajaran melalui kegiatan bermain dengan media tasru (kertas kokoru) dapat mengembangkan kemampuan motorik halus dalam menggulung pada anak usia 5- 6 tahun kelompok B PAUD (KB) AL-FIKR Banaran Kediri.

\section{SIMPULAN}

Berdasarkan hasil data yang diperoleh oleh peneliti, maka ditunjukkan bahwa kegiatan pembelajaran melalui bermain dengan media tasru (kertas kokoru) dapat mengembangkan motorik halus pada kelompok usia 5-6 tahun. Dengan adanya pembelajaran melalui bermain dengan media tasru ini, dapat menjadikan anak lebih semangat, lebih tertantang untuk berkreasi, berimajinasi sesuai kemampuan mereka masing masing, dan tentunya dapat melatih keterampilan gerak tangan dan jarijerami anak, sehingga dapat disimpulkan bahwa bermain dengan media tasru sangat berpengaruh untuk mengembangkan motorik halus anak usia dini.

\section{DAFTAR RUJUKAN}

Arikunto dadang iskandar. (2015). Penelitian Tindakan kelas yang mempunyai empat tahap yaitu perencanaan, pelaksanaan, pengamatan, dan refleksi.

Kementerian Pendidikan dan Kebudayaan Republik Indonesia. (2014). sifat-sifat kemampuan motorik halus anak usia 5 sampai 6 tahun adalah anak-anak dapat menarik yang ditunjukkan dengan pikirannya, meniru bentuk, menyelidiki dengan media dan latihan yang berbeda, menggunakan alat tulis dan peralatan makan secara efektif.

Suryani, R. (2014). Kerajinan Kokoeu Untuk Anak (Arcitra (ed.)).

Wulandari, S., \& Riyanto, A. A. (2018). Perluas Inovasi Melalui Media Kertas Kokoru pada Remaja Di 
TK Kartika Xix-43 Cimahi. CERIA (Brilliant Lively Responsive Imaginative Versatile), 1(3), 52. https://doi.org/10.22460/ceria.v1i3.p52-65

Tedjasaputra, M. S. (2001). Bermain, Mainan, dan Permainan. Jakarta:PT Grasindo

Departemen Pendidikan Nasional. (2007). Pedoman Pembelajaran: Bidang Pengembangan Fisik -

Motorik di Taman Kanak - Kanak. Jakarta: Departemen Pendidikan Nasional.

Aqib, Zainal. 2009. Penelitian Tindakan Kelas. Yrama Widya : Bandung.

Suyanto, Slamet. 2005. Proses Perkembangan Anak Usia Dini. Jakarta

Suharsimi Dkk. 2009. Peneliian Tindakan Kelas. Bumi : Jakarta

Endah. 2017. Perkembangan Motorik Kasar dan Motorik Halus. Http://Pembelajaran

guru.workpress.com/2008/05/25/Perkembangan Motorik Kasar dan Perkembangan Motorik Halus.

Amalia, M., Pransiska, R., \& Yulsofriend, Y. (2009). Pengaruh Kreasi Kertas Kokoru Terhadap

Perkembangan Kreativitas Anak Di Taman Kanak-Kanak Yakin Ringan-Ringan Kabupaten Padang

Pariaman. Jurnal IImiah POTENSIA, 4(2), 78-86. https://doi.org/10.33369/JIP.4.2.78-8

Hendraningrat, D. P. F. (2019) "Implementasi Kegiatan Menggulung, Menggunting, Menempel (3M) Melalui Kegiatan Bermain Kokoru Di Taman Kanak-Kanak Seroja Iman Samarinda," Pendidikan Anak Usia Dini, 10, hal. 109-116 